Jpn. J. Spec. Educ., 40 (6), 713-722, 2003.

\title{
Reviere
}

\section{Transition Support System in Japanese Special High Schools for Students with Intellectual Disabilities: A Comparison with the ITP Process in the United States}

\author{
Yumi MizUTANI* and Yuji YANAGIMOTO**
}

\begin{abstract}
The transition support system in Japanese special high schools for students with intellectual disabilities consists of two parts: career guidance and post-school assistance. Individualized transition support plans were introduced in Tokyo in 2001 in order to promote students' vocational independence and collaboration among schools, families, and local agencies. Tokyo's individualized transition support plans propose 2 separate fixed forms: individualized transition support plan (1) for career guidance and the individualized transition support plan (2) for post-school assistance. Some characteristics of the Japanese transition support system, including individualized transition support plans, are commonly found in the traditional individualized transition plans (ITP) process in the United States, such as the teacher-directed tendency. There seems to be nothing in common between the Japanese system and the person-centered ITP process in the United States.
\end{abstract}

Key Words: career guidance, post-school assistance, individualized transition support plans, individualized transition plans (ITP), personcentered planning

Individualized transition support plans were introduced at special high schools for students with intellectual disabilities in Tokyo and at some other special schools in the 2001 school year (Japanese Association of Special School Principals, 2002). Implementation of the plans seems to be strongly influenced by individualized transition plans (ITP) which have been practiced as transition service statements attached to the individualized education programs (IEP) in the United States since the passage of the Individuals with Disabilities Education Act of 1990 (IDEA, PL 101-476; Mizutani \& Yanagimoto, 2002).

The purposes of the present article are to review studies relating to the transition support system, including career guidance, post-school assistance, and individualized

*Doctoral Program of Disability Sciences, University of Tsukuba

** Institute of Disability Sciences, University of Tsukuba 
transition support plans, in Japan, and to examine the characteristics of the Japanese transition support system by comparing it with the ITP process in the United States, including traditional ITP and person-centered ITP.

\section{The Transition Support (Iko Shien) System in Japan}

\section{Career Guidance (Shinro Shido)}

In "Future Directions for Special Education in the 21st Century," the Japanese Ministry of Education, Culture, Sports, Science and Technology (2001) declared that one of the goals of special education was vocational independence for students with disabilities. As a result, recently, much research and many practical programs have been implemented to promote career guidance targeting vocational independence.

The Tokyo Public Special Schools for Students with Intellectual Disabilities' Association for Promoting Employment (2001) reported experimental practices on three themes: (1) dividing Tokyo into six regions for collaboration among schools and local agencies on the job placement of students; (2) task analysis of three popular categories of jobs for students with intellectual disabilities (i.e., service industries, clerical, and information processing); and (3) establishment of job support networks including schools and local agencies. The Tokyo Department of Education, Division of Instruction in Special Education (2001) reported that three themes emerged in the programs at special high schools in Tokyo: (1) fulfillment of career education in vocational courses at special high schools (e.g., an urban gardening course at Seicho Special High School); (2) fulfillment of career education in other courses at special high schools; and (3) career guidance focusing on fulfillment of career education.

Mizutani and Fujita (2001) surveyed the current practice of career guidance at special schools in Tokyo and found that the teachers specializing in career guidance coordinated transition support by referring to guidebooks (shinro no tebiki) and annual career guidance plans (nenkan shinro shido keikaku) originally developed by their own schools, that is, the teachers did not develop plans for career guidance individually. Hoshino (2002) surveyed department stores in Tokyo to ascertain employers' opinions and discussed the gap between employers and special education teachers, i.e., the employers requested that the students be accurate and have the ability to work, as well as have telephone conversation skills, while the teachers thought greeting was the most important work skill. This type of disparity might be resolved if individualized transition support plans were used as a tool to facilitate communication and common understanding among the people related to students' employment.

Individualized transition support plans are proposed to involve students, families, schools, agencies, and others in business or in the local community, in order to promote common understanding by the interdisciplinary team (Hara, 2002; Japanese Association of Special School Principals, 2002).

\section{Post-School Assistance (After-Care)}

Post-school assistance is not mandatory, but is often practiced as one function 


\section{Transition Support System in Japan and the ITP}

of transition support at special high schools in Japan. Post-school assistance includes continuing education at a special high school (seinen gakkyu), home visits, and followups at work. The importance of post-school assistance has been recognized for many years (Koide \& Ominami, 1984), and the schools agree to do it, however, the necessary funds have not been appropriated consistently (Otsuka Shinro Aftercare Kenkyukai, 1999).

Another issue is how long post-school assistance should be provided. In a national survey (Otsuka Shinro Aftercare Kenkyukai, 1999), the average answer was 3 years. Mizutani and Fujita (2001) supported those results, and suggested that 3 or 4 years post-school assistance probably matched the needs of graduates. They also argued that if only one teacher were in charge of career guidance, that individual might not be able to take care of the variety of post-school problems of all graduates, and their needs such as dismissal, graduates' hopes to leave/change their job, work attitude, job performance, and interpersonal relationships.

Mizutani, Hiruma and Yanagimoto (2002) surveyed 220 special high schools as to whether they had implemented post-school assistance. The results indicated that $44 \%$ of the schools were providing post-school assistance for graduates for at least 3 years after graduation; $36 \%$ provided assistance for all graduates; and $20 \%$ replied "other," including "depending on the case". Almost all teachers (96\%) answered that there was a need to place transition specialists in local agencies, especially for post-school assistance purposes.

Post-school assistance appears necessary even though there are issues relating to its non-mandatory status. Individualized transition support plans are expected to include post-school assistance, and consequently may contribute to the establishment of post-school assistance with local agency involvement.

\section{Individualized Transition Support Plans (Kobetsu Iko Shien Keikaku)}

In January 2001, the Japanese Ministry of Education, Culture, Sports, Science and Technology (2001) proposed that special school teachers collaborate with parents, private companies, and local agencies in order to develop individualized support plans for employment (kobetsu no shugyo shien keikaku) so that they can promote students' vocational independence through secondary special education. The same report also emphasized the importance of arranging for an array of supports for students with disabilities from their infancy to adulthood. The Japanese Association of Special School Principals (2002) defined individualized transition support plans as primarily for students who hope to be in competitive/supported employment, but the word "transition" was used instead of "employment" because the plans would cover not only work-related domains but also other domains, such as family life and recreation/leisure. So far, $15 \%$ of Japanese special high school teachers develop individualized plans for career guidance (Mizutani et al., 2002), and 13\% of teachers at special high schools for students with intellectual disabilities develop individualized transition support plans (Ogata, 2002).

The characteristics of individualized transition support plans that the Japanese 


\section{Y. Mizutani \& Y. Yanagimoto}

Association of Special School Principals (2002) proposed are: (a) two separate fixed forms: individualized transition support plans (1) for high school students and individualized transition support plans (2) for graduating students and graduates within 3 years; (b) focus on job-training or job placement and closely related to individualized plans for instruction; (c) development through a series of career counseling meetings (shinro sodan) held with students, parents, teachers, and possibly representatives from local agencies. The contents of each plan are shown in Table 1 . Other proposals for individualized transition support plans seem to have common characteristics with the above (Murakami, 2002), but one proposed plan includes domains, i.e., work-life, community life, family life, and recreation in plans both for high school students and for graduates (Nishimura, 2002). The importance of transition domains such as recreation and leisure in maintaining the motivation to work has been suggested (Mizutani, Ishida \& Yanagimoto, in press-b), and the individualized transition support plans tend to include these domains.

\section{Individualized Transition Plans in the United States and the Japanese Transition Support System}

Previously, we reviewed how the Japanese individualized transition support plans were introduced in order to facilitate career guidance and post-school assistance. Japanese special high school teachers who began to develop the plans are now seeking an effective way to involve students, their parents, and local agencies in the planning process (Tokyo Public Special Schools for Students with Intellectual Disabilities' Research Association for Promoting Employment, 2003) while the students and their parents' involvement in planning process has been secured in the United States by PL94-142 of 1975 and its amendments, as a result of which person-centered transition planning is recommended for implementation. In this chapter of the present article, we examine the characteristics of the two types of ITP in the United States, in order to identify common characteristics and differences compared with individualized transition support plans in Japan.

\section{Characteristics of ITP in the United States and the Japanese Individualized Transition Support Plans}

Recent ITP forms, for example, used in the Los Angeles Unified School District (LAUSD, 2000), consist of the factors shown in Table 1, which also depicts similarities and differences in individualized transition support plans (1), (2), and the ITP. We selected the Los Angeles Unified School District as an example because it is the largest school district in California that promotes person-centered planning in the ITP process. The individualized transition support plans (2) are more similar to the ITP, although the development of the plans (2) can be limited only once before graduation of the student. We find that only the plans (2) include the role of the school in the domains. That probably means that the school's role is more significant in Japan than in the United States for high school graduates, where local community agencies 
Transition Support System in Japan and the ITP

TABLE 1 Transition Support System in Japan and the United States

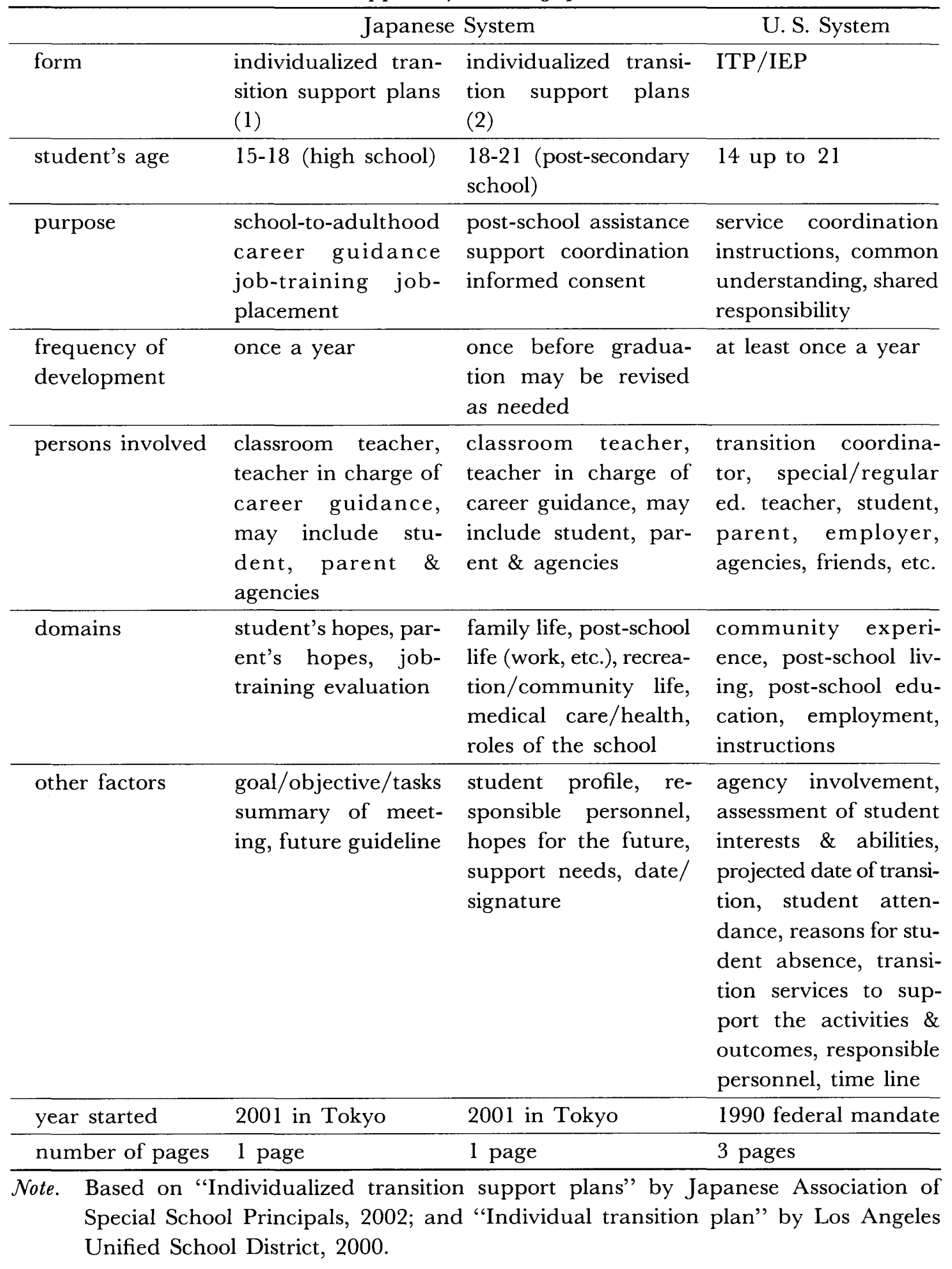


provide post-school assistance much more extensively. Student and parent involvement is essential in the ITP in the United States, where students', parents', and local agencies' involvement is optional in the Japanese system.

\section{The Japanese System and the Traditional/Person-Centered Individualized Transition Plans}

Recently, person-centered planning that is student-directed in nature, including greater involvement of the student's family, has been recommended in the ITP process (Bassett \& Lehmann, 2002; California Department of Education, 2001; Mizutani, Ishida, \& Yanagimoto, in press-a). Characteristics of both the traditional and person-centered ITP and the Japanese system are listed in Table 2. Five out of 13 items are commonly found both in traditional ITP and in the Japanese system. Those items are all related to the nature of planning meetings, such as whether they are teacher-directed or whether educational professionals are in control. Students tend to be passive service recipients, and students' parents are not significantly involved in the traditional ITP and the Japanese system. No items are in common between person-centered ITP and the Japanese system.

\section{Summary and Future Research}

Individualized transition support plans were introduced to promote collaboration among schools, families, and local agencies dealing with students. Some characteristics of the Japanese transition support system are common to the traditional ITP process in the United States, but there seem to be no commonalities between the Japanese system and person-centered ITP. Little research, however, has been done in order to prove the effectiveness of a person-centered ITP approach compared to the traditional type, although some experimental studies of the transition planning process, such as Allen, Smith, Test, Flowers, and Wood (2001) or Zhang (2001), demonstrated some effectiveness of self-directed IEP for developing student selfdetermination skills. Future research is needed, in order to evaluate the effectiveness of person-centered transition planning. 
TABLE 2 Japanese Transition Support System Gompared to ITPs in the United States

\begin{tabular}{|c|c|c|c|}
\hline & \multirow{2}{*}{ Japanese System } & \multicolumn{2}{|c|}{ U.S. System } \\
\hline & & Traditional ITP & Person-Centered ITP \\
\hline Orientation & $\begin{array}{l}\text { present/future, teacher- } \\
\text { directed, needs-based }\end{array}$ & $\begin{array}{l}\text { present, teacher-directed, } \\
\text { needs-based }\end{array}$ & $\begin{array}{l}\text { future, student-directed, } \\
\text { capacity-based }\end{array}$ \\
\hline $\begin{array}{l}\text { Values } \\
\text { Promoted }\end{array}$ & $\begin{array}{l}\text { vocational indepen- } \\
\text { dence, full participation, } \\
\text { equality }\end{array}$ & hierarchy & $\begin{array}{l}\text { self-determination, } \\
\text { inclusion, independence, } \\
\text { self-reliance }\end{array}$ \\
\hline Participants & $\begin{array}{l}\text { teacher only-may include } \\
\text { student, parents, \& ser- } \\
\text { vice providers' opinions } \\
\text { on a limited basis }\end{array}$ & $\begin{array}{l}\text { teacher selected-may } \\
\text { include service pro- } \\
\text { vider, not friends }\end{array}$ & $\begin{array}{l}\text { student selected-may } \\
\text { include friends, neigh- } \\
\text { bors, may not include } \\
\text { deliverers of services }\end{array}$ \\
\hline $\begin{array}{l}\text { Level of } \\
\text { Functioning }\end{array}$ & $\begin{array}{l}\text { based on vocational tests, } \\
\text { evaluation at job train- } \\
\text { ing and in classroom }\end{array}$ & $\begin{array}{l}\text { based on standardized } \\
\text { assessment scores, } \\
\text { focused on deficiencies }\end{array}$ & $\begin{array}{l}\text { ascertained by partici- } \\
\text { pants addressing stu- } \\
\text { dent's strengths }\end{array}$ \\
\hline Reco & $\begin{array}{l}\text { teacher-completed plan- } \\
\text { ning form }\end{array}$ & $\begin{array}{l}\text { teacher-completed plan- } \\
\text { ning form }\end{array}$ & $\begin{array}{l}\text { public display of meet- } \\
\text { ing notes by recorder }\end{array}$ \\
\hline Student Role & passive service recipient & passive service recipient & $\begin{array}{l}\text { leader, center of atten- } \\
\text { tion }\end{array}$ \\
\hline Educator's Role & $\begin{array}{l}\text { schedule \& conduct } \\
\text { meeting, ask opinions } \\
\text { from parents, evaluate } \\
\text { student in classroom, } \\
\text { facilitate }\end{array}$ & $\begin{array}{l}\text { schedule \& conduct } \\
\text { meeting, facilitate }\end{array}$ & $\begin{array}{l}\text { assist student in pre- } \\
\text { planning, maintain } \\
\text { focus, follow-up action } \\
\text { plan, help student } \\
\text { achieve goals, facilitate }\end{array}$ \\
\hline $\begin{array}{l}\text { Participant } \\
\text { Status }\end{array}$ & educational team in control & onal team in control & $\begin{array}{l}\text { parents, community } \\
\text { members, \& friends on } \\
\text { equal basis with profes- } \\
\text { sionals }\end{array}$ \\
\hline Com & $\begin{array}{l}\text { professionals address } \\
\text { parents, parents may } \\
\text { also address profes- } \\
\text { sionals }\end{array}$ & $\begin{array}{l}\text { professionals address } \\
\text { parents and profes- } \\
\text { sionals }\end{array}$ & student addresses \\
\hline $\begin{array}{l}\text { Agenda } \\
\text { Development }\end{array}$ & $\begin{array}{l}\text { based upon job-train- } \\
\text { ing, job-placement, etc. }\end{array}$ & $\begin{array}{l}\text { based upon necessary } \\
\text { forms (e.g., IEP, ITP) }\end{array}$ & $\begin{array}{l}\text { based on meeting pur } \\
\text { pose \& participant } \\
\text { ideas }\end{array}$ \\
\hline $\begin{array}{l}\text { Meeting } \\
\text { Logistics }\end{array}$ & at school around a table & at school around a table & $\begin{array}{l}\text { meeting location } \\
\text { selected for conve- } \\
\text { nience of participants; } \\
\text { comfort considered }\end{array}$ \\
\hline $\begin{array}{l}\text { Goal } \\
\text { Development }\end{array}$ & $\begin{array}{l}\text { based on community } \\
\text { resources }\end{array}$ & $\begin{array}{l}\text { based on 1-year incre- } \\
\text { ments }\end{array}$ & $\begin{array}{l}\text { derived from dreams of } \\
\text { desired future }\end{array}$ \\
\hline $\begin{array}{l}\text { Follow-up } \\
\text { Activities }\end{array}$ & teacher-driven & teacher-driven & $\begin{array}{l}\text { listed on action plan, } \\
\text { include support of par- } \\
\text { ticipants }\end{array}$ \\
\hline
\end{tabular}

Note. From "Student-focused conferencing and planning" by D. S. Bassett and J. Lehmann, 2002, p. 49. Copyright 2002 by Pro-Ed. 


\section{References}

Allen, S. K., Smith, A. G., Test, D. W., Flowers, G., \& Wood, W. M. (2001) The effects of "self-directed IEP" on student participation in IEP meetings. Career Development for Exceptional Individuals, 24, 107-120.

Bassett, D. S. \& Lehmann, J. (2002) Student-focused conferencing and planning. Pro-Ed, Austin, TX.

California Department of Education (2001) Transition to adult living: A guide for secondary education. Author, Sacramento, CA.

Hara, T. (2002) Tokyo-to ni okeru kobetsu iko shien keikaku no kokoromi [Individualized transition support plans in Tokyo: A pilot study]. Paper presented at the 40th conference of the Japanese Association of Special Education, Joetsu, Japan. (in Japanese)

Hoshino, S. (2002) Chiteki shogaiji no ippan shuro ni muketa shokugyo kyoiku ni kansuru kenkyu: Kigyo no needs o ikasu shiten kara [Vocational education for students with intellectual disabilities who seek competitive employment: Employers' perspectives]. Nakasatsunai Koto Yogogakko [Nakasatsunai Special High School], Hokkaido, Japan. (in Japanese)

Japanese Ministry of Education, Culture, Sports, Science and Technology (2001) 21 seiki no tokushukyoiku no arikata ni tsuite: Hitori hitori no needs ni oujita tokubetsuna shien no arikata ni tsuite [Future directions for special education in the 21st century: Suggestions for special services depending on individual needs]. Author, Tokyo. (in Japanese)

Japanese Association of Special School Principals (2002) Shogaijisha no shakaisanka o susumeru kobetsu ikoshien keikaku [Individualized transition support plans: Promoting participation by individuals with disabilities]. Kyoiku Shinsha, Tokyo. (in Japanese)

Koide, S. \& Ominami, H. (Eds.) (1984) Shosetsu seishin hattatsuchitaiji no shinro shido to sotsugyo-go shido [Career guidance and post-school assistance for students with mental retardation and developmental disabilities]. Gakushu Kenkyusha, Tokyo. (in Japanese)

Los Angeles Unified School District (2000) Individual transition plan (ITP form, commodity code \#9661279006-7, 9661279033). Author, Los Angeles.

Mizutani, Y. \& Fujita, K. (2001) Shinro shido to kobetsu no shido keikaku ni kansuru kenkyu: ITP model sakusei ni mukete [A study on transition assistance and individualized education programs: For the future development of the ITP models in Japan]. Bulletin of Special Education, 25, 101-110.

Mizutani, Y., Hiruma, T., \& Yanagimoto, Y. (2002) A nationwide investigation of individualized plans in Japanese special high schools: Implications for the collaborative practices of individualized transition support plans. The Japanese Journal of Special Education, 39(6), 41-58.

Mizutani, Y., Ishida, S., \& Yanagimoto, Y. (in press-a) America gasshukoku no ITP process ni okeru person-centered planning: California shu deno sakusei houhou ni shoten o atete [Person-centered planning: Five steps for developing person-centered ITP in the State of California]. Shinshin Shogaigaku Kenkyu [Bulletin of Special Education]. (in Japanese with English abstract) 
Mizutani, Y., Ishida, S., \& Yanagimoto, Y. (in press-b) Japanese young adults with mental retardation and their transition needs: Post-school case studies. Career Development for Exceptional Individuals.

Mizutani, Y. \& Yanagimoto, Y. (2002) America gasshukoku ni okeru ITP no hatten keii to genjo [Individualized transition plans: Process of its development and current practices in the United States]. Shinshin Shogaigaku Kenkyu [Bulletin of Special Education], 26, 177-192. (in Japanese with English abstract)

Murakami, T. (2002) Kobetsu iko shien keikaku ni tsuite: Jirei [Individualized transition support plans: A case study]. Shogaino aru kodomo no tameno kyoiku sodan taikeika suishin jigyo shiryo [Promoting systematic educational counseling for children with disabilities: Results of an empirical study]. Takeyama Yogo Gakko [Takeyama Special School], Kanagawa, Japan. (in Japanese)

Nishimura, S. (2002) Honko no iko shien no kokoromi [Transition support at Utsunomiya University, Department of Education Affiliate Special High School: A pilot study]. Paper presented at the 40th Conference of the Japanese Association of Special Education, Joetsu, Japan. (in Japanese)

Ogata, N. (2002) Kobetsu iko shien keikaku sakusei ni kanrensuru yogogakko no jokyo: Zenkoku chosa yori [Individualized transition support plans: A nationwide investigation of current practice at special schools]. Paper presented at the 40th conference of the Japanese Association of Special Education, Joetsu, Japan. (in Japanese)

Otsuka Shinro Aftercare Kenkyukai (1999) Chitekishogai yogogakko ni okeru shinro aftercare no jittai to kadai: Zenkoku seishinhakujaku yogogakko anketo chosa kenkyu hokokusho [Career guidance and post-school assistance at special schools for students with intellectual disabilities: A report of a nationwide survey of current practices and issues as seen by special schools for students with mental retardation]. Tsukuba University Affiliated Otsuka Special School for Students with Intellectual Disabilities, Tsukuba, Japan. (in Japanese)

Tokyo Department of Education, Division of Instruction in Special Education (2001) Heisei 12 nendo toritsu yogogakko shokyugyo kyoiku suishin-ïnkai hokokusho: Jidai no henka ni taioshita shokugyokyoiku no jujitsu tayona shokugyokyoiku to aratana shinroshido no tenkai [Promoting career education at special schools in Tokyo in the 2000 school year: Committee reports on fulfillment of career education accorded with the change of time, development of diverse career education, and new career guidance]. Author, Tokyo. (in Japanese)

Tokyo Public Special Schools for Students with Intellectual Disabilities' Association for Promoting Employment (2001) Heisei 11-12 nendo mogakko, rogakko, oyobi yogogakko shugyo sokushin ni kansuru chosa kenkyu: Tokushukyoiku shogakko, rodo, fukushi kankeikikan, kigyo nado no renkei o hakatta kokatekina shokugyokyouiku oyobi shinroshido nado no arikata ni kansuru kenkyu dai 2 nenji chosa kenkyu hokokusho. [Promoting employment of students graduating from schools for students with visual impairments, schools for students with hearing impairments, and special education schools in the 1999-2000 school year: The 2nd annual report on effective career education and transition assistance for collaboration of special education schools, vocational and welfare agencies, and private companies]. Author, Tokyo Department of Education, Tokyo. (in Japanese)

Tokyo Public Special Schools for Students with Intellectual Disabilities' Research Associa- 


\section{Y. Mizutani \& Y. Yanagimoto}

tion for Promoting Employment (2003) Heisei 14, 15 nendo monbu kagakusho ishoku jigyo shugyo shien ni kansuru jissen kenkyu dai 1 nenji jissen kenkyu hokokusho-kobetsu iko shien keikaku QEA kisohen: Hitori hitori no needs ni ojita shakaisanka eno support [The action research project requested by the Japanese Ministry of Education, Culture, Sports, Science and Technology in the 2002-2003 school year for promoting employment, the action research report in the first year: Individualized transition support plans basic manual to support students' participation based on individual needs]. Tokyo Department of Education, Tokyo. (in Japanese)

Zhang, D. (2001) The effect of "Next S.T.E.P." instruction on the self-determination skills of high school students with learning disabilities. Career Development for Exceptional Individuals, 24, 121-132.

-Received September 30, 2002; Accepted February 3, 2003 - 